\title{
Public Policy Exception in the Enforcement of Arbitral Awards in Nigeria
}

\author{
Uchenna Ponfa Emelonye1, Uchenna Emelonye ${ }^{2,3,4^{*}}$ \\ ${ }^{1}$ Department of Commercial Law, University of Exeter, Exeter, UK \\ ${ }^{2}$ University of Helsinki, Helsinki, Finland \\ ${ }^{3}$ University of Derby, Derby, UK \\ ${ }^{4}$ United Nations Office of the High Commissioner for Human Rights, Monrovia, Liberia \\ Email: ^emelonye@gmail.com
}

How to cite this paper: Emelonye, U. P., \& Emelonye, U. (2021). Public Policy Exception in the Enforcement of Arbitral Awards in Nigeria. Beijing Law Review, 11, 266-286. https://doi.org/10.4236/blr.2021.121016

Received: November 3, 2020

Accepted: March 28, 2021

Published: March 31, 2021

Copyright $\odot 2021$ by author(s) and Scientific Research Publishing Inc. This work is licensed under the Creative Commons Attribution International License (CC BY 4.0).

http://creativecommons.org/licenses/by/4.0/

\begin{abstract}
In contemporary times, the value of international commercial transactions in goods services has increased alongside globalisation and consequently translated on the flip side to increased prospects of commercial disputes. Although litigation through the court processes has hitherto been the default mechanism for the resolution of commercial disputes, it is manifestly clear that in the present era of globalisation and digital age, it is not always the most effective and efficient way of dealing with commercial disputes. In Africa, arbitration has gained traction and increasingly used to resolve international commercial disputes within and outside the continent. Regardless of its inherent strengths, international commercial arbitral awards are enforceable only through the domestic legal systems and to the extent that the arbitral awards are compatible with national laws and standards including public policy. In view of the foregoing, this work undertakes, from a comparative perspective, an in-depth analysis of the public policy exemption to the enforcement of arbitral awards in Nigeria. The significance of this research that concentrates on the public policy exception to the recognition and enforcement of foreign arbitral awards in Nigeria, as against other aspects of international commercial arbitration, is because the recognition and enforcement of foreign arbitral awards are the most important and crucial part of the whole process of international commercial arbitration. It also intends to analyse public policy defence as articulated in several enforcement conventions and laws, particularly the New York Convention on Recognition and Enforcement of Arbitral Award, the UNCITRAL Model Law on International Commercial Arbitration and the Nigerian Arbitration and Conciliation Act.
\end{abstract}

\section{Keywords}

Nigeria, Arbitration, Arbitral Awards, Public Policy, Exceptions, Commercial 
and Enforcement

\section{Introduction}

In contemporary times, the value of international commercial transactions in goods services has increased alongside globalisation and consequently translated on the flip side to increased prospects of commercial disputes. There is no gainsaying the fact that due to considerable increase of international business transactions, commercial disputes are also on the increase. Although litigation through the court processes has hitherto been the default mechanism for the resolution of commercial disputes, it is manifestly clear that in the present era of globalisation and digital age, it is not always the most effective and efficient way of dealing with commercial disputes.

As such, the weaknesses in litigation as a means of resolving commercial disputes have given rise to alternative dispute resolution mechanisms such as arbitration which has been in ascendance as the global mechanism of choice for resolving commercial disputes over litigation mainly due to the Convention on the Recognition and Enforcement of Foreign Arbitral Awards (the New York Convention), which has greatly eased the enforcement of foreign arbitral awards. In general terms, arbitration may be described as a method to resolve any disputed issue between the relationships of concerned parties on the basis of a predetermined arbitration agreement and led by an arbitrator or arbitrators, who derive their authority by special agreement between the parties to a dispute. In other words, arbitration is a procedure in which a submitted dispute is derived from the agreement of the parties based on an arbitration clause that defines the cause of action jointly predetermined by the parties to resolve potential disputes arising from the trade relationship.

Despite the initial objection to international commercial arbitral process because its rules and procedures conflicted significantly with national laws and rules, it has in recent years, emerged to be one of the most user friendly mechanisms for resolving international commercial disputes. In the continent of Africa, arbitration has gained traction and increasingly used to resolve international commercial disputes within and outside the continent. It has also facilitated inter-regional global business climate and trade and ultimately served as essential mechanism for efficient disposal of disputes arising out of and between business transactions.

Regardless of its inherent strengths, international commercial arbitral awards are enforceable only through the domestic legal systems and to the extent that the arbitral awards are compatible with national laws and standards. As such, the scope of international commercial arbitration is limited because it grants countries the discretionary authority to decline enforcement or recognition of foreign awards (Graham, 1987). Similarly, the enforcement of arbitral awards nevertheless, depends deeply on domestic legal mechanism of member states in which case domestic courts can refuse the enforcement of international arbitral awards 
if such enforcement would be contrary to their public policy (Sheppard, 2004).

In Nigeria for instance, whereas the default mechanism for resolving disputes, including trade disputes is through the court processes, the trend is gradually changing with the courts overwhelmed with variety of cases and the protracted turnaround time it takes a commercial dispute to emanate from the High Court and graduate to the Court of Appeal and ultimately subjected to the final adjudication of the Supreme Court. As the world's $7^{\text {th }}$ largest oil reserves Nigeria is an important business hub on the African continent.

On average, it takes 454 days to enforce through the courts. With the nation's importance as a vastly growing global economy and one of Africa's leading international business and trade nations, this long waiting time for the resolution of disputes through the courts negatively effects business interests and investors' confidence. It is no longer news in Nigeria that by the time a commercial dispute is transported from the bottom to the apex of the court hierarchy in Nigeria, the subject of the dispute and the outcome of the case might be worthless to the party in whose favour the matter was determined. Consequently, it has become expedient for commercial disputants in Nigeria to seek expeditious forms of dispute resolution by inserting arbitral clauses in their contract with the aim of referring disputes arising out of the contract or transaction to a forum for alternative dispute resolution.

As a significantly more private, more consensual, and expedited alternative compared to standard court processes, arbitral agreements and awards are ostensibly easier to enforce. But in practice, this is not always the case because after succeeding in arbitrating a dispute, the enforcement of such arbitral awards at the national level are often fraught with challenges, including for reasons of public policy considerations raised by relevant states. In view of the foregoing, this work undertakes, from a comparative perspective, an in-depth analysis of the public policy practice as exemption to the enforcement of arbitral awards in Nigeria. The significance of this research that concentrates on the public policy exception to the recognition and enforcement of foreign arbitral awards in Nigeria, as against other aspects of international commercial arbitration is because the recognition and enforcement of foreign arbitral awards are very, if not the most important and crucial part of the whole process of international commercial arbitration.

On the other hand, the success and failure of international commercial arbitration are eventually measured by post-arbitral proceedings dealing with the recognition and enforcement of foreign arbitral awards. This is because, international commercial arbitration would not be said to be successful if the award rendered could not be recognized and enforced in Nigeria or elsewhere. It is the expectation of the authors that this work would contribute to knowledge and provide a deeper understanding of the similarities and dissimilarities between Nigeria and other related jurisdictions. This work is also valuable and will contribute ultimately to the effectiveness of the enforcement of foreign arbitral awards in Nigeria. 
Relying on the contemporary normative framework of commercial arbitration and the benefits of arbitral awards over litigation in globalized and interconnected economy, this work will examine through a comparative perspective the public policy defence applied in some jurisdictions, including Nigeria to refuse recognition and enforcement of foreign arbitral awards. It also intends to analyse public policy defence as articulated in a number of enforcement conventions and laws, particularly the New York Convention on Recognition and Enforcement of Arbitral Award, the UNCITRAL Model Law on International Commercial Arbitration and the Nigerian Arbitration and Conciliation Act.

Noting that public policy is a controversial term in commercial arbitration and subject to discrepant interpretation and application, this work will endeavor to calibrate the fluid definition of public policy, the fact that different states have different meanings and interpretation of what is public policy and finally the fact that whereas the enforcement of an arbitral award may be refused in one country because of public policy considerations, it may be enforced in another country, even though both countries are Contracting Parties of relevant normative frameworks.

This work postulate and conclude that although Nigeria and other countries have interpreted the public policy defence in an expansive and possibly protectionist manner to refuse enforcement, this is not a trend that is gaining traction. Rather, the restrictive and pro-enforcement definitions of public policy espoused by most countries, particularly the United Kingdom and India is effectively undermining the potency of the public policy defence as a means of refusing enforcement of foreign arbitral awards.

\section{Normative Framework for Commercial Arbitration}

The normative foundations of international commercial arbitration emerged during the second half of the twentieth century governed by multiple levels of legal regimes and various national legal systems. The global normative framework for international commercial arbitration is predicated on the Geneva Protocol of 1923 and the Geneva Convention of 1937 (Born, 2011). Noting the weaknesses of the 1927 Geneva Convention, the international Chamber of Commerce (ICC) advocated for the adoption of another international arbitration instrument to replace the 1927 Convention (Gaillard \& Savage, 1999). In 1958, the Convention on the Recognition and Enforcement of Foreign Arbitral Awards, commonly known as the New York Convention was adopted.

Article I (1) of Convention provides that the application of the Convention shall relate to recognition and enforcement of arbitral awards that are made in the "territory" of a state "other than the state where the recognition and enforcement of such awards are sought". The second of this provision further provides that the Convention shall apply to arbitral awards "not considered" as domestic awards in the State where their recognition and enforcement are sought. Providing universal enforceability of arbitral awards, the adoption of the New 
York Convention is a significant milestone in the history of international commercial arbitration because it became a universal constitutional charter for international arbitral procedure, and enabled arbitral tribunals and national courts to develop efficient means for enforcing international arbitral awards and agreements (Baykitch \& Hui, 2008).

As one of the most ratified international conventions, the New York Convention not only deals in parallel with recognition and enforcement but it entrenched recognition and enforcement of foreign and non-domestic awards in countries where arbitral awards are sought (Gaillard \& Savage, 1999). Coming into force at a time of growing importance of international arbitration as a means of settling international commercial dispute, and being one of the most important steps towards a uniform system of international arbitration, the New York Convention created a unique, autonomous and distinct global normative framework governing international commercial arbitration. It seeks to provide common legislative standards for the recognition of arbitration agreements and court recognition and enforcement of foreign and non-domestic arbitral awards. Requiring Contracting States to ensure that foreign arbitral awards are granted due recognition and enforcement in the same way as domestic arbitral awards, the principal aim of the Convention is to ensure that both foreign and non-domestic arbitral awards are implemented by contracting states.

The New York Convention was complemented by the United Nations Commission on International Trade Law (UNCITRAL MODEL LAW), which provides universal enforceability of awards to make sure that foreign and non-domestic arbitral awards will not be distinguished and discriminated against (Baykitch \& Hui, 2008). It obliges member states to guarantee that such awards are recognized and enforced in the same way that domestic awards are enforced.

Whereas other relevant regional and international conventions and national statues contributed to the consolidation of global arbitral processes, the role of national legislations and domestic courts were inestimable in expanding and consolidating arbitral awards and thus provide the jurisprudence within which international arbitration was implemented at the domestic levels. Among these differentiated levels of national and international normative governance of arbitration, the national legal systems are at the epicenter and hold a unifying position for international commercial arbitration. This is the case because national legal systems domesticate arbitral conventions and determine in practice, the extent and effect of any arbitral agreement and awards.

While the national and international arbitration frameworks standalone individually, they are nevertheless inter-related and mutually reinforcing. This is because, international arbitration agreement will only be effective in the local context, to the extent of the scope granted to it by the national frameworks (Born, 2011). As such, the independence of international commercial arbitration from national legal systems is not in absolute terms because, in realty, international commercial arbitration heavily leans on the national legal systems. 


\subsection{Commercial Arbitration in Nigeria}

At the national level, the first Arbitration statue in Nigeria is the Arbitration Ordinance 1914 which was re-enacted as the Arbitration Ordinance Act Cap 13, Laws of the Federation of Nigeria and Lagos, 1958. The 1958 Act did not make reference to international arbitration and was as such limited to domestic arbitration only (Isau, 2013). It was not until 1988 that the first indigenous statute on Arbitration, known as the Arbitration and Conciliation Decree 1988 was enacted and reenacted in 2004 as the Arbitration and Conciliation Act (ACA) Cap A18 Laws of the Federation of Nigeria (2004). The ACA was the first UNCITRAL Model law based provision in Africa and contains 4 parts of provisions listed in section 1 to 58 (Asouzu, 2001).

On the other hand, Nigeria has ratified the International Centre for settlement of Investment Disputes Convention in 1965 and domesticated it through the International Centre for Settlement of Investment Disputes (Enforcement of Awards) Act 1967. It is also a party to regional conventions regarding the recognition and enforcement of arbitral awards including the Economic Community of West African States (ECOWAS) Energy Protocol, which under article 26 provides for disputes arising from contracting states and investors to be settled by the International Centre for Settlement of Investment Disputes.

Overall, there is no gainsaying the fact that the ACA generally applies to international arbitration in Nigeria. It applies to both being both domestic and international arbitration proceedings and to all arbitrations which hold a seat in Nigeria or have been agreed by the parties to be governed by ACA. As a Contracting State and signatory of some other regional Conventions concerning the recognition and enforcement of arbitral awards, the New York Convention provides in Nigeria the enabling framework for ensuring common legislative standards for the recognition of arbitration agreements and enforcement of foreign arbitral awards.

It also encourages and entrenches in Nigeria due recognition and enforcement of arbitral awards on the same strength as domestic arbitral awards and further seeks to ensure that foreign and non-domestic arbitral awards are not discriminated against in Nigeria. Despite being a Contracting State, the New York Convention was domesticated in Nigeria through Schedule 2 to the Arbitration and Conciliation Act 1988 Cap. A18 Laws of the Federation of Nigeria 2004.

The 1988 ACA, congregates both the provisions of the New York Convention and the UNCITRAL Model Law and provides a unified legal framework for the fair and efficient settlement of commercial disputes by arbitration and conciliation. It also makes applicable in Nigeria any award arising out of international commercial arbitration and made pursuant to both Conventions. Under Article 48(a)(i) and Article 52(a)(i), parties to the arbitration agreement in Nigeria must have pre-requisite legal capacity under the law applicable. Its purport is that in other for an arbitration to be valid and recognized in Nigeria, it must be deemed valid under the laws of the nation or to the laws selected by the parties. 
Accordingly, parties to an arbitration in Nigeria are free to choose either the New York Convention or the UNCITRAL Model Law as the law governing the proceedings, but where they have not predetermined the law, the arbitral proceedings will be governed by ACA. In any case, under Section 15(1) and (2) of ACA, the party's autonomy is applicable only to the extent that they do not conflict with statutory restrictions in the country.

As a federal State, both state and federal governments can legislate therefore allowing for the existence of arbitration laws by individual states of the federation. As a general rule and pursuant to Section 1 of the ACA, the basic legal requirement in Nigeria for an arbitral agreement is that the agreement must be in writing or be contained in a written document which has been signed by both parties. Additional legal requirements provided in the ACA for a valid arbitration agreement, include more universally familiar articles, namely article 48 and 52 of the ACA, which elaborates that an arbitral agreement must be in relevance to a dispute capable of settlement by arbitration under the provided laws of $\mathrm{Ni}$ geria.

Section 52 of the ACA sets out the legal requirements for enforcement of arbitral award including that it must not be contrary to public policy. Also, an arbitral award is final and binding and can only be challenged on limited grounds as stipulated in ACA including the recognition or enforcement of the award is against public policy of Nigeria. Beyond these, an award cannot ordinarily be challenged in substance.

On the other hand, Nigerian courts are favorably inclined to enforcing arbitration agreements and have held in the case of C.N. Onuselogu Ent. Ltd. v. Afribank (Nig.) Ltd. that once there is a voluntary agreement to submit, arbitration is a good and valid alternative dispute resolution mechanism. According to Section 4 and 5 of the ACA, where there is an arbitration clause in a contract which is the subject of court proceedings, a party to the court proceedings may promptly raise the issue of an arbitration clause and the courts will stay proceedings and refer the parties to arbitration.

This was the ratio in the case of Transnational Haulage Limited v. Afribank Nigeria Plc \& Anor. In Niger Progress Ltd. v. N.E.I. Corp. the Supreme Court followed section 5 of ACA, which gives the court the jurisdiction to stay proceedings where there is an arbitration agreement. Similarly in the case of M.V. Lupex V. N.O.C, the Supreme Court held that it was an abuse of court process for the respondent to institute a fresh suit in Nigeria against the appellant on the same dispute during the pendency of the arbitration proceedings in London.

Even though the ACA did not stipulate any particular subject matter that may not be referred to arbitration, not all disputes are necessarily arbitrable as the question of whether or not a dispute is arbitrable is therefore left for interpretation by the courts. In the case of Ogunwale v. Syrian Arab Republic the Court of Appeal held that the test for determining whether a dispute is preferable to arbitration is that the dispute or difference must necessarily arise from the clause con- 
tained in the agreement. Regardless, as with other jurisdictions, non-commercial and non-civil matters are not arbitrable and not all arising disputes are arbitrable. Further support is shown in section 57(1) of the ACA which defines arbitration as a commercial arbitration.

\subsection{Enforcement of Commercial Arbitral Awards}

Contracting Parties to an arbitration have a legitimate expectation that their disputes will be resolved and the autonomy of their contracts respected and enforced by the courts. After an arbitral tribunal renders an award, it cannot be enforced by the same tribunal, but rather through separate proceedings at the country where the award debtor has sufficient assets to satisfy the award. This is because arbitral awards are not self-executing like national court judgments. Enforcement of arbitral awards is regulated by Article III of the New York Convention and transfers recognition and enforcement of foreign arbitral awards to national courts. It provides that:

Each Contracting State shall recognize arbitral awards as binding and enforce them in accordance with the rules of procedure of the territory where the award is relied upon, under the conditions laid down in the following articles.

Similarly, Article IV sets out the conditions to be fulfilled by a party seeking enforcement of an award falling within the scope of the New York Convention. It stipulates that an applicant for enforcement is to produce the original award or a duly certified copy and the original arbitration agreement or a duly certified copy thereof. In fulfilling these conditions, the party seeking enforcement is to produce prima facie evidence entitling it to obtain enforcement of the award. It is then up to the other party to prove that enforcement should not be granted on the basis of the grounds (Adekoya, 2015).

Other than the New York Convention, another relevant international instrument for the enforcement of arbitral awards is the UNCITRAL Model Law on International Commercial Arbitration (1985). It was adopted as a model or uniform law to revise the New York Convention and harmonize the enforcement arbitral awards. Attempting to obliterate existing obstacles to the recognition and enforcement of arbitral awards, the UNCITRAL simplified the arbitration progress with its rules widely accepted in many jurisdictions. It created uniform rules to eliminate local peculiarities which make international consistency impossible in certain areas of law. The UNCITRAL Model Law has undergone a revision in 2006 to introduce new features and improve its legislative framework.

Article 35 and 36 of the UNCITRAL Model Law provides for the recognition and enforcement of arbitral awards irrespective of the country in which it was made and also provides grounds for refusal to enforce an arbitral award. Noting that an arbitral award is not self-executing like court judgments, they cannot be enforced by the courts that make the pronouncement, rather, through separate 
proceedings at the jurisdiction, national or international where the award debtor has sufficient assets to satisfy the award.

This is because arbitration is a transnational dispute resolution mechanism based on the understanding that the scope of an arbitral tribunal in international commercial arbitration is not a local court of a particular country that is limited to a single country. According to Article III of the New York Convention, arbitral awards shall be enforced in accordance with the rules of procedure of the territory where the award is relied upon. Consequently, the enforcement of foreign arbitral awards is national in orientation and subject to the rules of procedures of country of enforcement, including grounds such as public policy. But where there is no reason to refuse enforcement of an award, then a domestic Court is enjoined to issue a decree or court order for enforcement in favour of the Applicant upon the lodging of the original or certified copy of the arbitral award and arbitration agreement in court.

Regardless of the enforceability of arbitral awards under Article V (2) (b) of The New York convention, there are express exceptions whereby a foreign arbitral award is not enforceable either by the defendant party or a national court by own notion' (Roy, 1994). In that case, the party challenging or resisting enforcement in whole or part of an award has the responsibility to prove why the award should not be enforced based on the grounds provided in Article V.

\subsection{Arbitral Enforcement in Nigeria}

As has been hitherto mentioned, Nigeria domesticated the New York Convention through the introduction of the Second Schedule of the Arbitration and Conciliation Act 1988 Cap A18 Laws of the federation of Nigeria 2004, and as such foreign arbitral award can be enforced in Nigeria pursuant to the ACA, the New York Convention or the UNCITRAL Model Law because arbitral awards allowed judgments under section 2 of the ACA. According to Order 52 rule 17 of the Federal High Court Civil Procedure Rules,

Where an award is made in proceedings on an arbitration in a foreign territory to which the foreign Judgment (Reciprocal Enforcement) Act extends, if the award was in pursuance of the law in force in the place where it was made; it shall become enforceable in the same manner as a Judgment given by a court in the place and the proceedings of the Foreign Judgments (reciprocal Enforcement) Act shall apply in relation to the award as it applies in relation to a Judgment given by that court.

Enforcement of arbitration in Nigeria is governed by the ACA especially Section of 51 which grantees the recognition of an award regardless of the jurisdiction in which it was granted. Also under Section 32, parties seeking an award must provide the courts at the point of application for enforcement with relevant documents including duly authenticated original award or a certified copy; a copy of the original arbitration agreement or a certified copy; and a duly certified translation in the English language of the award if the award was not 
granted in the English language.

This position of the law is elucidated in the case of Ebokam v. Ekwenibe, where the court of appeal listed additional requirements for parties seeking recognition and enforcement under the New York Convention. The preliminary step in the enforcement of commercial arbitral awards in Nigeria is first and foremost the registration of the award under the Foreign Judgment Act which allows for a six-year time period for the enforcement and recognition of a foreign judgment. It is common knowledge that since not all arbitral awards are accepted in good faith, its enforcement is prone to challenges in most countries including in Nigeria. According to Order 39 Rule 4 of the High Court of Lagos State Civil Procedure Rules, a party seeking to enforce or even set aside an arbitral award can do so with a notice accompanied with an affidavit validating the award. Lagos is the most developed state with arbitration laws and thus has become the centre for arbitration in Nigeria.

Bearing in mind that parties to an arbitration agreement are not seized with the assistance of a process servers as is the case in national courts and recognizing that the effectiveness of international arbitration depends to a large extent on its enforceability, it becomes necessary for the award creditor to seek enforcement of the award at the place where the award debtor has assets which can satisfy the judgment of the award. In seeking such recognition and enforcement, national courts are granted wide latitude to enforce of arbitral awards or do otherwise.

As a member state of the Common Wealth of nations, foreign awards may also be enforced in Nigeria through the Reciprocal Enforcement of Judgments Act 1922, which was created to ensure fluidity in registration and enforcement of court judgments obtained in the United Kingdom, including arbitral awards, so long as the award is enforceable in the country in which the award was handed down. It is important to note however that it was established in the case of Macaulay v R.Z.B. of Austria that only superior court judgments from these countries are to be recognised and enforced in Nigeria. Similarly, the disposition of the courts in relation to the enforcement of arbitral awards in Nigeria was also exhibited in the case of Ras Pal Gazi Construction co, Ltd vs F.C.D.A, that "It is very clear and without any iota of doubt, that an arbitral award made by an arbitrator to whom a voluntary submission was made by the parties to the arbitration, is binding between the parties".

Since foreign judgments in Nigeria are additionally regulated by the Foreign Judgments (Reciprocal Enforcement) Act, Cap F35, Laws of the Federation of Nigeria, 2004, courts in Nigeria are to recognise and enforce arbitral awards in the absence of any deliberating factors and convincing grounds for setting aside the awards. For a foreign award to be recognised in Nigeria, relevant parties must adduce evidence showing that the award was registered in the country of origin. This is emphasized in the case of Tulip v Noleggioe.

The conditionality of reciprocity of arbitral enforcements is not a prerequisite 
to the enforcement of an arbitral award. In Topher Inc v Edokpolor, the court held that:

A party is not prevented from suing upon a foreign judgment regardless of whether there is a reciprocal treatment in the country where it is obtained, if no order is made under section 124 to modify that position ... A suit brought upon a foreign award ought not to be struck out merely on the ground that there must be a treaty guaranteeing reciprocal treatment in the country where it was made or an Order in Council to that effect.

\section{Public Policy Exemption of Arbitral Awards}

Whereas the New York Convention and other related conventions govern recognition and enforcement matters and were enacted to guarantee the international respect necessary for domestic courts to enforce private foreign arbitral awards, the situation is that international arbitral agreements contain certain exceptions under which the courts may legally refuse to enforce a foreign arbitral award. One of such exemptions is the public policy. The meaning of the public policy exception to the enforcement of arbitral awards depends heavily on the courts own motion of what composes "public policy".

Accordingly, the New York Convention contains a public policy exception that permits domestic courts to refuse to enforce a foreign arbitral award if the award violates the public policy of the nation in which enforcement is sought. This ground of refusal is provided based on article V (2)(b) of the New York Convention, which provides that " Recognition and enforcement of an arbitral award may be refused if the competent authority in the country where recognition and enforcement are sought finds that: (b) The recognition or enforcement of the award would be contrary to the public policy of that country."

The public policy provision of the Convention has generated much attention and debate probably because it was on the one hand left for the local courts of the country of enforcement to decide and on the other hand because there is no clear codification of any specific group of issues that should be regarded as public policy applicable. Compared to all other ground provided under the Convention on which enforcement of foreign arbitral awards can be refused, the public policy ground is highly susceptible to abuse because of its imprecise definition and the fact that what constitutes public policy differs from one country to another

Public policy has been known as "multi-faceted", "open-textured and flexible" with "various guises" and hence a "vast variety in the vocabulary and ambiguities". The legislatures and courts are, reasonably, hesitant to describe public policy thoroughly. Public policy defense as an estoppel against the enforcement of arbitral awards could be raised by the party contesting the enforcement or by the courts of the host country on their own volition (Cole, 1986).

On the other hand, the UNCITRAL Model Law also contains elements of public policy exemptions to the effect that international arbitral awards are valid 
subject to a certain annulment grounds for foreign arbitral awards. These grounds are similar to the defense of public policy exemption contained in the New York Convention (Born, 2011). It provides in Art 34 that "public policy" can be a ground for setting aside an award by the courts at the seat of the arbitration and a ground for refusing recognition and enforcement of a foreign awards.

While Article V.2(b) of New York Convention and Article 36 of the UNCITRAL Model law refer to the public policy of the state in which enforcement is sought, there was no attempt in both instruments to harmonize the definition or application of the term "public policy". Arguing that public policy as used in both the Model Law and the New York Convention extend to fundamental principles of law and justice in substantive as well as procedural respects, both conventions adopt a broad interpretation of the public policy exemptions which are capable of undermining the strength and the effectiveness' of both instruments and in turn casts doubts on their effectiveness.

The public policy provision in the Model Law and the New York Convention has generated heated academic debates and disagreement than any other provisions of both conventions. It could be argued that this could be linked to the fact that the application of the public policy exemption is subject to the determination and interpretation of local courts of the country of enforcement. Conversely, the controversy revolving on the issue of public policy could because there is no codification of any specific group of issues that should be regarded as public policy applicable to foreign arbitral awards under the Convention and Model Law.

Arguing that the public policy referred to in Article V 2(b) of the Convention is that of the enforcement country, the public policy of the seat of arbitration if different from the country of enforcement does not have any relevance in the public policy that is contemplated in the Convention and Model Law. As much as the wordings of the Model Law and New York Convention on public policy are clear, some school of thought still postulate that the public policy that is being contemplated is not the domestic public policy of enforcement country, but an international one (Racine, 1999). These protagonists believe that if the public policy contemplated is international, then there would not be undue interference in the enforcement of foreign arbitral awards by the judicial authority of the enforcement country on the basis of public policy. For instance, the recommendation of International Law Association Committee on International Commercial Arbitration (Mayer et al., 2002),

The expression "international public policy" is used in these Recommendations to designate the body of principles and rules recognized by a State, which, by their nature, may bar the recognition or enforcement of an arbitral award rendered in the context of international commercial arbitration when recognition or enforcement of said award would entail their violation on account either of the procedure pursuant to which it was rendered (procedural international public policy) or of its contents (substantive interna- 
tional public policy).

The Committee further recommended that the principles to be taken into account by a court in the determination of public policy should be those considered fundamental within its own legal system, rather than those relating to the context of the law governing the contract, the law of the place of performance of the contract or the law of the seat of arbitration.

Despite the Model Law and the New York Convention, other conventions provide public policy exemptions. For instance, the 1927 Geneva Convention stated in Article 1(e)) "that an award would be enforceable unless contrary to the public policy or to the principles of the law of the country in which it is sought to be relied upon. Similarly, the 1975 Panama Convention makes reference to the "public policy exception of that State". Also, the 1979 Montevideo Convention, the 1983 Riyadh Convention and the Amman Convention all provide that enforcement may be refused if the award is "contrary to public policy or good morals of the signatory State where enforcement is sought".

\section{Application of Public Policy Exemption in Nigeria}

At the national level, public policy exemption is found in a number of national legislation in varying and considerable degrees. Although neither the Arbitration and Conciliation Act nor the courts in Nigeria have explicitly defined the concept of public policy, it is generally at the root of the defense of illegality and connotes breach of Nigerian law or State policies. According to Sections 48(2)(b)(ii) and 52(2)(b)(ii) of ACA, public policy as a major ground for setting aside or refusing the enforcement of an arbitral award in Nigeria. Under Section 48 (b)(ii) of the Arbitration and Conciliation Act, the court may set aside an arbitral award if the court finds that the award is against public policy of Nigeria or that the recognition or enforcement of the award is against public policy or recognition or enforcement of the award would be contrary to the public policy of that country.

In Nigeria, arbitration is effective alternative dispute resolution mechanism available to courts under the relevant rules of procedures. This positive approach of Nigeria courts to the application of public policy exemptions in Nigeria was elucidated in the case of Onuselogu Ent. Ltd. v. Afribank (Nig.) Ltd, where the court held that arbitral proceedings are not to be taken lightly by the parties or the counsel, but rather should be recognised as a means of resolving disputes. Where an arbitration clause exists in a contract undergoing court proceedings, the case has been, a party can raise the issue of the arbitration clause and the proceedings will be promptly stayed and referred to arbitrations by the courts, such as in the case of Transnational Haulage Limited v Afribank Nigeria Plc \& Anor.

Similarly, in Niger Progress Ltd. v. N.E.I. Corp, the courts relied on Article 4 and 5 of the ACA to state the court has jurisdiction to stay proceedings where there is an arbitration agreement. Furthermore and reinforcing fair and pro- 
cedural arbitral process, the court in M.V. Lupex v. N.O.C, held that it would be an abuse of the court process for the respondent to institute a fresh suit in Nigeria against the appellant body on the same arbitral dispute that was ongoing in London. At the state level and based on section 6(3) and section 21 of the Lagos State Arbitration Laws 2009, courts in Nigeria are permitted to make interim orders and reliefs in other to preserve the rights of the parties pending an arbitration. This is coupled with article 13 of the ACA which gives the arbitral tribunal power to make interim orders before or during the arbitral proceedings.

In Soleimany v. Soleimany, breach of public policy could be procedural in nature and manifest in the case of fraud in the composition of the tribunal, breach of natural justice, lack of impartiality, lack of reasons in the award, manifest disregard of the law, manifest disregard of the facts, annulment at place of arbitration. Alternatively, it could be substantive in the form of breach of mandatory rules, fundamental principles of law, actions contrary to good morals and national interest/foreign relations, etc.

In regard to conducting arbitration and enforcing arbitral awards in the country, Nigeria contains a handful of arbitration institution and centres. One of the most prominent institutions is the Lagos Court of Arbitration. This centre acts as the nation's main international centre for arbitration and trade. The Lagos Court of Arbitration (LCA) is an independent International Centre for the resolution of commercial disputes, established under the Lagos Court of Arbitration Law No. 172009.

\section{Comparative Perspective of Public Policy Exemption of Arbitral Awards}

For purposes of the comparative analysis of the application of public policy in the enforcement of arbitral award so as to better understand the context and practice in Nigeria, few countries that share similar legal system in Nigeria and drawn from multiple continents will be considered. Chief amongst these countries is the United Kingdom from where Nigeria derived its independence and inherited its legal systems.

United Kingdom is a Contracting Party for the New York Convention subject to the "reciprocity" reservation and is governed at the domestic level by the Arbitration Act 1996 which covers domestic as well as international arbitration. Being a country with bias towards the enforcement of arbitral awards pursuant to the New York Convention, Section 103(3) of the 1996 UK Arbitration Act, includes public policy as one of the grounds for refusal of recognition or enforcement of a foreign arbitral award. As such, courts in the United Kingdom have shown reluctance to refuse enforcement of an award on the basis that it is contrary to public policy.

As a signatory to the New York Convention, courts in the UK are obliged to enforce awards made in a State that is also party to the Convention. In the case 
of Soinco SACI \& Anor. v. Novokuznetsk Aluminium Plant \& Ors., the court declined an application to refuse enforcement of an arbitral award on the ground that compliance with the award would offend the law of the place of incorporation of the respondent company. There are also instances in the UK where courts have refused to enforced arbital awards based on public policy. For instance, in Westacre Investment Inc. v. Jugoimport-SPDR Holding Co. Ltd, the court held that a contract involving bribes would only be contrary to English domestic public policy if the contract contravenes the domestic public policy of the country where it is to be performed. Similarly, in the case of Soleimany $v$. Soleimany, the English Court of Appeal refused to enforce an arbitration award on the ground of public policy. The court thus stated:

The parties cannot override that concern by private agreement. They cannot use arbitration ... to enforce an illegal contract. Public policy will not allow it. It may be that they expected that the award, whatever it turned out to be, would be honoured without further argument. It may be that the plaintiff can enforce it in some place outside England and Wales. But enforcement here is governed by the public policy of the lex fori.

In another Court of Appeal case of David Taylor \& Son Ltd. v. Barnett, the court also refused to enforce an arbitral award on the ground that the contract between the parties was illegal and therefore in conflict with the public policy of the country.

Within the African continent, Kenya is a member of the Commonwealth of Nations with Nigeria and shares the same Common Law legal system. Kenya is also a signatory to and has domesticated the New York Convention and the UNCITRAL Model Law. In defining the term "public policy" Justice Ringera, J. (as he then was) stated that an award could be set aside under Section 35 (2) (b) (ii) of the Kenya Arbitration Act on the grounds that it offends public policy if it was shown that such award was inconsistent with the Constitution or other laws of Kenya whether written or unwritten, inimical to the national interest of Kenya or contrary to justice and morality. Also, in Kenya Shell Limited $v$ Kobil Petroleum limited, the court pointed out that as a matter of public policy, it is in the public interest that there should be an end to litigation and the Arbitration Act under which the proceedings in this matter were conducted underscores that policy. Likewise, in the case of Tanzania Electric Supply Company limited v Dowans Holdings $S A$, the court dismissed the petition on the grounds of public interest.

In the same vein the end this review of the scope of interpretation of public policy on the African continent, noting that Zimbabwe has modified the text of the UNCITRAL Model Law with regard to the public policy exception to its enforcement, but its modification has been interpreted as emphasising the limited nature of the public policy exception. Zimbabwe's Arbitration Act 2002 supplements the wording of the Model Law, providing in Article 34(5) that

[f]or the avoidance of doubt ... it is declared that an award is in conflict with 
the public policy of Zimbabwe if (a) the making of the award was induced or effected by fraud or corruption; or (b) a breach of the rules of natural justice occurred in connection with the making of the award

In Zesa v. Maposa, this additional wording led the Zimbabwe Supreme Court to construe the public policy defence restrictively in accordance with the pro-enforcement character of the New York Convention. Specifically, the Zimbabwe Supreme Court reasoned that

An award may be refused on the basis of public policy only where it was based on so fundamental an error, and constituted an inequity so far-reaching and outrageous in its defiance of logic or acceptable moral standards, that a sensible and fair-minded person would consider that the conception of justice in Zimbabwe would be intolerably hurt by the award.

Outside the African continent and within Asia, India also shares legal boundaries with Nigeria as a common law nation, its 1996, Arbitration Act entrenches minimal judicial intervention in the arbitral process. However, Indian courts have been inclined to interfere with foreign arbitral awards at the award-enforcement stage on grounds of public policy. Under the 1996 Act, an arbitral award can be refused on public policy grounds if the award is found to be "contrary to (i) fundamental policy of Indian law; or (ii) the interests of India; or (iii) justice or morality." In 2003, the Indian Supreme Court extended this already sweeping public policy exception to include "patent illegality." The Indian Supreme Court in the case of Renusagar Power Plant Co. Ltd v. General Electric Co decided that an award may be contrary to public policy if enforcement is contrary to (i) the fundamental policy of Indian law; or (ii) the interests of India; or (iii) justice or morality. The Court stated thus:

It is obvious that since the Act is calculated and designed to sub serve the cause of facilitating international trade and promotion thereof by providing for speedy settlement of disputes arising in such trade through arbitration, any expression or phrase occurring therein should receive, consisting with its literal and grammatical sense, a liberal construction.

This decision was in consonance with the narrow interpretation of the public policy exception widely accepted by most developed nations. The Supreme Court endorsed the fact that only when faced with extreme violations of public policy should the national courts interfere with foreign arbitral awards. Also, it held that the national courts should not use the public policy exception as an excuse to delve into the merits of the foreign award. Unfortunately, the Indian Supreme Court decision in Renusagar has not been followed by subsequent decisions of the Indian courts.

Despite the protectionist approach of the Indian courts, it took a different trajectory in interpreting the public policy defence in the case of Oil \& Natural Gas Corp (“ONGC”) v. Saw Pipes where the Indian Supreme Court rejected the nar- 
row interpretation of public policy ground was given in the Renusagar case since the concept of public policy included matters that concerned "public good and public interest." The Supreme Court set aside the award on grounds of public policy on the basis that the arbitral tribunal had erred when it concluded that ONGC had to prove its loss in order to seek liquidated damages.

Realizing the impact of this jurisprudence on the economic growth of the country, the Indian Government decided to bring about certain legislative changes in order to address the problems created by these decisions. In 2010, it launched changes to the Indian Arbitration Act to deal with the excessive interference of the Indian courts in foreign arbitral awards and proposed that "fundamental policy of India, the interests of India or justice and morality" be the three heads under which an award could be set aside under the public policy ground. Post 2010, recent decisions by Indian courts have shown a change in attitude towards the defence of public policy. In Penn Racquet Sports v. Mayor International Ltd., the court upheld an arbitral award and rejected the claim that the award violated public policy. The Court stated that a mere violation of Indian public policy will not suffice in setting aside a foreign arbitral award. For a petition to set aside an arbitral award to be successful, the Court held, it must have violated the fundamental policy of Indian law, the interests of India, justice and morality.

In the case of Indonesia which is another common law country with a legal system inherited from the UK and similar to Nigeria, the adoption of national public policy exceptions to foreign arbitral awards has been subject to very wide interpretations. The Indonesian courts have given a wide interpretation to the public policy defence and have on several occasions even been averse to referring disputes to the arbitration tribunal on the ground that the agreement containing the arbitration clause is in violation of Indonesian public policy. For instance, in the case of Perusahaan Listrik Negara (PLN) v. Paiton, the courts denied the submission by the defendant that the court had no jurisdiction to try the dispute because the agreement between the parties contained an arbitration clause. In denying his submission, the court stated that the agreement containing the clause was the subject matter of the dispute and that if the agreement is void, every clause in it is in essence also void. The court declared that an Indonesian court is permitted to examine and render a decision on the merits even though the agreement between the parties included an arbitration clause, if the agreement contravenes Indonesian public policy.

Courts in Indonesia have set aside international arbitration award using the rationale of economic protectionism. They have strived to protect economic goals by imposing constraints on enforcement through the concept of "the national interest". An example is the annulment by Indonesia's Jakarta Central District Court of an award rendered by an arbitration panel in Geneva, Switzerland in Karaha Bodas v. Pertamina and PLN. In this case, an Indonesian court asserted jurisdiction over the dispute between the parties, and annulled the 
award on an unprincipled ground of economic protection. It is gratifying to note that the award was later overturned by the state's Supreme Court that came to the conclusion that arbitral award was domestically enforceable. The Supreme Court in coming to this conclusion found that the decision of the lower court violated the "separability" principle, which is expressly recognized in the Arbitration Law of Indonesia.

The Philippines also seems to lean towards giving a wide interpretation to the scope of the public police defence. A court in Manila refused enforcement of a foreign arbitral award because it found that an award made in Singapore violated Philippine's public policy for failing to apply Philippine law as required by the contract, caused unjust enrichment, applied the "costs follow the event" rule, and awarded attorney fees.

Outside the countries operating the common law system, Non Common Law countries, a number of national laws adopt the public policy term in there legislations through the use of different names. Notwithstanding the differences in semantics, the purpose of the public policy defence or whatever called is the same and directed at protecting the good morals and public interest. Countries like Lebanon, Algeria, Portugal, Japan, Libya, Oman, Qatar, Jordan, Tunisia, Romania, France and the United Arab Emirates expressly refer to public policy or public order. Others including Austrian make a distinction between mandatory laws and the basic principles of the Austrian legal system". Also, Polish legislation provides that an award will not be enforced if it "offends the legality or the principles of social coexistence in the Polish People's Republic.” The legislation of Sweden states that enforcement of a foreign award may be refused if the court finds that "it would be clearly incompatible with the basic notions of the Swedish legal system to recognize and enforce the award. The legislation of the Republic of Korea requires that "a foreign judgment be compatible with 'good morals and the social order of the Republic of Korea". In China, the legislation refers to enforcement of a foreign award it may refuse if it "goes against social and public interest."

\section{Conclusion and Recommendations}

Arbitration is governed by the New York Convention and UNCITRL Model law in collaboration with national arbitration laws. These arbitration frameworks attempt to provide a common legislative standard for recognition and enforcement of foreign arbitral awards. Notable amongst the Convention's aims is to ensure that foreign arbitral awards are not discriminated against at the enforcement stage. However, there are some potential challenges in ensuring that the Convention achieves the drafters' aims.

The increasing choice of arbitration as medium for resolving commercial disputes is certainly due to its advantages and value addition over litigation, including the alacrity at which arbitral proceedings are handled and the fact that the successful party emerges with a legally binding and enforceable award ob- 
tained in a way and manner that does not terminally harm the business relationship between the parties. Another low hanging dividend of commercial arbitration is that parties to a commercial transaction or contract, who have resorted to arbitration, have the rear opportunity of contractually determining a wide range of issues relating to the substance and processes for the resolution of foreseeable and unforeseeable disputes.

Since parties to arbitration can take their destinies in their hands, and bearing in mind the informality of the processes, they can circumvent intrinsic complexities and technicalities of litigation, maintain confidentiality of the arbitration process so as to protect the essence of transactions between the parties and by so doing avoid such delays necessarily linked to ligation. The foregoing is not a suggestion that arbitration is not without flaws. Bearing in mind that the success of commercial arbitration is dependent on national judiciaries that will enforce eventual awards and the national legal framework to govern such enforcement, commercial arbitration is fraught with so many conditionalities including public policy.

A review of national practice of arbitration shows discrepant practices whereby some countries are inclined to either protectionist or expansionist interpretation of public policy. Depending on the approach of the country in question, national courts may either be prone to enforce or refuse to enforce arbitral awards based on the broad or restrictive interpretation and application of the public policy. The reason is because the Convention localizes the enforcement of foreign arbitral awards, leaving the authority of discretion to the enforcing country. Thus, concluding that leaving enforcement of foreign arbitral awards at the discretion of authority of the enforcement country would not do much harm than leaving the interpretation of one of the vital provisions of what determines whether a foreign arbitral award should be enforced or not to the authority of the enforcement country.

Whereas United Kingdom, India and other developed economies are restrictively applying the public policy concept to ensure optimal enforcement of arbitral awards, the reverse is the case in Nigeria where a broad sweep and scope of the public policy concept is limiting the enforcement of arbitral awards. There is no gainsaying the fact that public policy exemptions should be applied very narrowly and only in the most restricted circumstances. However, there are plethora of decisions in Nigeria using the public policy defence to refuse enforcement of foreign arbitral awards. The interpretation of what should constitute public policy should not be left in the hands of Nigerian courts to decide given that the arbitral award is a product of international treaty, international business transaction, and as well a product of international tribunal. Where the protectionist regime continues in Nigeria, the resultant effect is that investors' enthusiasm and confidence in Nigeria maybe soon be eroded and may negatively impact on foreign direct investment and ultimately the economy at large.

Based on the global trend vis-à-vis the situation in Nigeria, the reliance on 
public policy as anti-enforcement measures will not thrive for a long time to come but will certainly fade away with the passage of time. It is postulated that the evolving pro-enforcement momentum will continue and perpetuate the laudable gains of arbitration irrespective of the fact that public policy is a defense on the enforcement of arbitral awards. It is for this reason amongst others that Nigeria should join the pro-enforcement comity of nations utilizing and appropriating the gains of arbitration and benefit of the enforcement of arbitral awards.

Noting that nothing is good that cannot be better and nothing is great that cannot be greater, it is hereby recommended that the text of the New York Convention and UNCITRAL Model Law could certainly be improved to ensure stricter interpretation of the public policy. On the part of the ACA, it should be amended so that it can be given the same protectionist interpretation applicable in common law countries such as United Kingdom and India. On the other hand, the text of these normative frameworks could be improved to address the lacuna in the definition of what is public policy instead of leaving it to the discretion of the enforcement country. This can be achieved by mandating the UNCITRAL Working Group on Arbitration to define the term "public policy" applicable to the Convention.

Additionally, it is recommended that there should be a model law legislation that attempts to harmonize what is considered public policy in relation to the enforcement of foreign arbitral awards in the Contracting States. The essence of the effort would be to aggregate principles that will be to serve the highest interests of the world community and the common interests of mankind.

\section{Conflicts of Interest}

The authors declare no conflicts of interest regarding the publication of this paper.

\section{References}

Adekoya, F. (2015). The Public Policy Defence to Engagement If Arbitral Awards: Rising Star or Setting Sun? BCDR International Arbitration Review, 2, 203-222.

Asouzu, A. (2001). International Commercial Arbitration and African States: Practice, Participation and Intuitional Development (p. 120). Cambridge: Cambridge University Press.

Baykitch, A., \& Hui, L. (2008). Celebrating of 50 Years of New York Convention. UNSW Law Journal, 31, 364-371.

http://www.austlii.edu.au/au/journals/UNSWLJ/2008/20.pdf

Born, G. (2011). International Arbitration: Cases and Materials (p. 27). Hague: Kluwer Law International.

Cole, R. (1986). The Public Policy Exception to the New York Convention on the Recognition and Enforcement of Arbitral A ward (1985-1986) (p. 366).

https://core.ac.uk/download/pdf/159598227.pdf

Ebokam v. Ekwenibe \& Sons Trading Company, (2001) NWLR 2 (Pt. 696), 32.

Gaillard, E., \& Savage, J. (1999). Fouchard Gaillard Goldman on International Commercial Arbitration (2nd ed., p. 122). Hague: Kluwer Law International. 
Graham, W. P. (1987). Remarks by William P. Graham. Proceedings of the ASIL Annual Meeting, 81, 372-373. http://doi.org/10.1017/S0272503700069743

Isau, A. (2013). The Role of Arbitration Agreement in Resolving Disputes Arising from Commercial Transactions.

https://www.academia.edu/3699960/The Role of Arbitration Agreement in resolvin g disputes in Commercial Transaction

Karaha Bodas Company LLC v. Perusahaan Pertambangan Minyak Dan Gas Bumi Negara \& PT. PLN (Persero) (Dec. 18, 2000).

Macaulay v R.Z.B of Austria (2003) 18 NWLR (Pt. 852) 282.

Mayer et al. (2002). Members of the Committee; International Law Association, New Delhi Conference (2002) Committee on International Commercial Arbitration, 5. https://www.google.com/url? sa=t\&rct=j\&q=\&esrc=s\&source=web\&cd=\&ved=2ahUKE widg9OSzszvAhVRzYUKHZCZCf4QFjAAegQIAhAD\&url=https\%3A\%2F\%2Fila.vetto reweb.com\%2FStorage\%2FDownload.aspx\%3FDbStorageId\%3D1136\%26StorageFileGui d\%3D6da5d26c-c8ee-4989-95e5-9bd1589282d3\&usg=AOvVaw2T3cxIPwbYQ0wXjUiF $\underline{\mathrm{X} 5 \mathrm{bz}}$

Penn Racquet Sports v. Mayor International Ltd., (2011) 122 DRJ 117 (India).

Racine, L. (1999). L'Arbitrage Commercial International et l'Order Public (p. 441).

Ras Pal Gazi Construction Co. Ltd v F.C.D.A (2001) LPELR-SC.45/96.

Renusagar Power Plant Co. Ltd. v. General Electric Co. (1994). SC 860 (India).

Roy, K. (1994). The New York Convention and Saudi Arabia: Can a Country Use the Public Policy Defense to Refuse Enforcement of Non-Domestic Arbitral Awards. Fordham International Law Journal, 18, Article 9.

http://ir.lawnet.fordham.edu/cgi/viewcontent.cgi?article=1425\&context=ilj

Sheppard, A. (2004). Public Policy and the Enforcement of Arbitral Awards. http://www.transnational-dispute-management.com/article.asp?key $=48$

Soinco SACI \& Anor. v. Novokuznetsk Aluminium Plant \& Ors. Court of Appeal, England and Wales (Dec. 16, 1997) [1998] CLC 730.

Soleimany v. Soleimany [1998] APP.L.R. 02/19.

Topher Inc of New York v Edokpolor (Trading as John Edokpolor \& Sons) (1965). 1 All NLR 1, 307.

Tulip Nig. Ltd v Noleggioe Transport Maritime S.A.S (2011). NWLR 4 (Pt.1237), 254.

Westacre Investment Inc. v. Jugoimport-SPDR Holding Co. Ltd. [1999] 3 ALL ER.

Zesa v. Maposa (2) ZLR 452 (s) (1999) (Zimbabwe). 